\title{
Recovery of patients after four months or more in the persistent vegetative state
}

\author{
Keith Andrews
}

A retrospective review was made of the case notes of 43 consecutive patients admitted to a unit specialising in the rehabilitation of people in the persistent vegetative state. Eleven of these patients regained awareness four months or more after suffering brain damage. The time to the first reported incidence of eye tracking was between four months and three years, and the time to the first response to command was between four and 12 months. Only one patient was eventually unable to communicate, six could use non-verbal methods of indicating at least a yes or no response, and four were able to speak. Six patients remained totally dependent while two became independent in daily activities. Four patients became independent in feeding, three required help, and four remained on gastrostomy feeding.

Thus some patients can regain awareness after more than four months in a vegetative state, and, although few reach full independence, most can achieve an improved quality of life within the limitations of their disabilities. The recovery period is prolonged and may continue for several years. Even patients with profound brain damage should be offered the opportunity of a specialist rehabilitation programme.

The persistent vegetative state is the most severe form of brain damage. The term, coined by Jennett and Plum ${ }^{1}$ describes a group of patients who, though having a pattern of sleeping and waking, show no meaningful responses to changes in their environment except at a reflex level. The term differentiates from those patients in coma, who do not open their eyes and show no reflex response to stimulation. The proportion of patients in the persistent vegetative state varies between $1 \%$ and $12 \%$ of those in coma for longer than 24 hours, depending on the time of assessment..$^{2-11}$ Higashi et al estimated an incidence for the persistent vegetative state (from all causes) of 2.5 per 100000 of the population. ${ }^{12}$ Sazbon $e t$ al estimated the prevalence of patients in a vegetative state because of trauma to be about four cases per million of the population. ${ }^{13}$ Since many of these patients die at an early stage the number in the persistent vegetative state is probably less than 1000 in the United Kingdom, but they require a large amount of resources.

Patients in the persistent vegetative state are generally thought to have a very poor prognosis, and Jennett and Dyer have argued for them to have "the right to die." ${ }_{14}$ This view has been highlighted by the recent case of Anthony Bland, when the courts agreed that withdrawal of artificial feeding would not be unlawful. Jennett has also argued that "the recovery of a limited degree of awareness may indeed be worse than nonsentience for that patient, whatever satisfaction it may bring to carers." 15 These views raise several questions: whether patients in the persistent vegetative state for several months can recover, and, if so, by how much and after how long; whether there are features which give clues to a patient's prognosis; and whether severe disability is worse for non-sentience.

Several studies have described the poor outcome of people in the persistent vegetative state for longer than one month. ${ }^{16-20}$ Probably the largest study is that of Braakman et al, in which 10 of the 49 patients who were still in a vegetative state after three months regained consciousness, but all remained severely disabled at the end of the first year after brain damage. ${ }^{16}$

There are, however, several reports of late recovery. Bricolo et al described the recovery of 90 patients in the vegetative state who survived the first year. Of these, 20 started to obey commands more than three months after the brain injury, and seven made a good recovery or reached moderate levels of ability. Other studies have described recovery of awareness by patients after 6-12 months of being in a vegetative state..$^{161-24}$ Although a few patients became independent in daily activities, most remained dependent on others. A long term follow up of 84 patients in the persistent vegetative state (by means of information from the Traumatic Data Bank) showed that most eventually became conscious: 34 by six months, nine more between six and 12 months, and another five between one and $2^{1 / 2}$ years. ${ }^{25}$ In a five year follow up of 30 patients in the persistent vegetative state five recovered awareness between one and five years. Only two, however, recovered to a level where they could communicate, read, write, watch television, calculate simple mathematical addition and subtraction, tell the time, feed themselves, and be wheelchair independent. ${ }^{26}$

Although a patient in a vegetative state due to anoxia is generally thought to have a very poor prognosis, Rosenberg et al described the case of a man aged 43 who was in a vegetative state for 17 months after anoxic brain damage before showing the first signs of awareness. He progressed to being able to tell stories and jokes, though he was unable to recognise complex collections of objects in pictures and was unable to read. ${ }^{27}$ Other reports of recovery after a considerable length of time include that of a woman aged 18 who, after being in a vegetative state for $2^{1 / 2}$ years, progressed to being able to comprehend and communicate, take a considerable interest in her environment, and establish interpersonal relationships. ${ }^{28}$ A 25 year old woman remained in a vegetative state for six years before recovering..$^{29}$ After 14 months of rehabilitation she was able to feed, groom, and dress herself and, with some assistance, to transfer herself from bed to chair. Her speech and cognitive ability also improved.

The reports raise doubts about the view that no worthwhile recovery can occur after three months in the persistent vegetative state. The purpose of the present study was to examine the case histories of patients in the persistent vegetative state who were admitted to a rehabilitation unit specialising in profound brain damage in order to assess the eventual outcome of those who first showed awareness four months or more after suffering brain damage.

\section{Patients and methods}

A retrospective review was made of the case notes of patients admitted to the Persistent Vegetative State Rehabilitation Unit of the Royal Hospital and Home, Putney, a charity specialising in the management of 
people with profound disabilities. There was no preselection of patients for rehabilitation other than that they were medically stable and did not require artificial ventilation. During the first five years of the unit's existence 43 patients in a vegetative state were admitted, and 22 were discharged. The case notes of 11 of these patients showed that they had been in a persistent vegetative state for at least four months before showing a return to awareness, and all were included in the study.

The records of the medical, nursing, therapy, dietetic, psychology, and social work departments were examined to ensure the accuracy of the data for this study. In the determination of when awareness returned two levels of awareness were chosen: eye tracking (that is, following a moving object or person with one's eyes) and responding to a command (for example, to blink or squeeze a hand). Since neither of these levels are sudden events the time was recorded when the response occurred on several occasions.

The rehabilitation programme for these patients included the provision of optimal nutrition (most of the patients admitted to the unit were underweight), control of infections, management of bladder and bowel, control of posture, provision of specialised seating, and inclusion of a programme of sensory stimulation.

Information from the referring hospital was not always available and was usually limited. In most cases the results of computed tomography were provided, but these were usually from shortly after the brain injury and few patients were scanned again later.

\section{Results}

The table shows details of the 11 cases, including the time taken to start eye tracking and obeying commands and the eventual outcome. The first sign of returning awareness was eye tracking, which occurred 4-6 months after brain damage in eight cases. In one case this occurred as late as three years after brain damage. The ability to obey commands occurred later, though in about half of the cases it occurred within one month of eye tracking. The eventual outcome was usually achieved only after prolonged rehabilitation, although for those being transferred home some of this time was spent in waiting for homes to be modified.

Only one patient (case 2 ) remained unable to communicate any needs. Four patients were eventually able to speak, and six were able to use non-verbal methods such as aids and computers to communicate some basic needs at least. Four patients became independent in feeding, four required some help to feed by mouth, and three required feeding by gastrostomy. Only three patients became independent in personal care, including one who required supervision, but one other was able to instruct carers as to her needs and two could make some contribution to washing and dressing. Four patients were eventually able to walk, though only one had a normal gait.

All but one of the patients had some degree of cognitive impairment. Two were able to make appropriate decisions about complex matters, four were able to cope in a structured environment, two showed appropriate pleasure reactions to changes in the environment, and two remained profoundly cognitively impaired.

Only one patient (case 10) showed obvious distress at his condition. He had been a professional and fully appreciated his poor physical recovery. All the other patients were able to take pleasure from environmental changes within the limits of their cognitive ability.

Case 2, which did not fit into the general pattern of recovery, raises some ethical problems. The patient, a 25 year old man who had developed severe cerebral anoxia during anaesthesia, showed no signs of recovery until he started to eye track about three years after the brain damage. Although he did not respond to commands, he laughed appropriately at cartoons on

Details of patients recovering from the persistent vegetative state after four months or more

\begin{tabular}{|c|c|c|c|c|c|c|c|c|c|c|c|c|c|}
\hline \multirow{2}{*}{$\begin{array}{l}\text { Case } \\
\text { No }\end{array}$} & \multirow{2}{*}{$\begin{array}{c}\text { Sex and age } \\
\text { (years) } \\
\text { (at brain } \\
\text { damage } \\
\end{array}$} & \multirow{2}{*}{$\begin{array}{c}\text { Cause of brain } \\
\text { damage }\end{array}$} & \multirow[b]{2}{*}{$\begin{array}{l}\text { Results of computed } \\
\text { tomography }\end{array}$} & \multicolumn{3}{|c|}{$\begin{array}{l}\text { Time to reach level of awareness } \\
\text { (months) }\end{array}$} & \multicolumn{6}{|c|}{ Level of ability } & \multirow[b]{2}{*}{ Placement } \\
\hline & & & & $\begin{array}{c}\text { Eye } \\
\text { tracking }\end{array}$ & $\begin{array}{c}\text { Obeying } \\
\text { commands }\end{array}$ & $\begin{array}{l}\text { Eventual } \\
\text { outcome }\end{array}$ & Communication & $\begin{array}{c}\text { Comprehension } \\
\text { and cognition }\end{array}$ & Feeding & Personal care & Mobility & Mood & \\
\hline 1 & M 16 & $\begin{array}{l}\text { Pedestrian in a } \\
\text { road traffic } \\
\text { accident }\end{array}$ & $\begin{array}{l}\text { Cerebral contusions } \\
\text { mid brain, right } \\
\text { temporal, both } \\
\text { frontal lobes, and } \\
\text { basal ganglia }\end{array}$ & 5 & 12 & 18 & $\begin{array}{l}\text { Foot switch for yes or } \\
\text { no responses }\end{array}$ & $\begin{array}{l}\text { Good auditory } \\
\text { understanding, } \\
\text { good sense of } \\
\text { humour }\end{array}$ & Most by mouth & Totally dependent & Totally dependent & Generally good & Home with family \\
\hline 2 & M 25 & $\begin{array}{l}\text { Anaesthetic . } \\
\text { anoxia }\end{array}$ & Not available & 36 & NA & 60 & $\begin{array}{l}\text { Focusing on person } \\
\text { talking to him }\end{array}$ & $\begin{array}{l}\text { Laughing at } \\
\text { humorous } \\
\text { situations }\end{array}$ & Gastrostomy & Totally dependent & Totally dependent & $\begin{array}{l}\text { Varies in response to } \\
\text { presence or } \\
\text { absence of wife }\end{array}$ & Home with wife \\
\hline 3 & M 52 & Assault & $\begin{array}{l}\text { Diffuse cerebral } \\
\text { atrophy }\end{array}$ & 5 & 6 & 30 & $\begin{array}{l}\text { Clear speech, able to } \\
\text { express needs and } \\
\text { concerns }\end{array}$ & $\begin{array}{l}\text { Lack of } \\
\text { organisational } \\
\text { skills, initiates } \\
\text { coping strategies }\end{array}$ & Independent & $\begin{array}{l}\text { Independent with } \\
\text { supervision }\end{array}$ & Walking but ataxic & Motivated & $\begin{array}{l}\text { Private nursing home } \\
\text { because of lack of } \\
\text { family support }\end{array}$ \\
\hline 4 & M 21 & Assault & $\begin{array}{l}\text { Right temporal lobe } \\
\text { haematoma and } \\
\text { marked oedema }\end{array}$ & 4 & 5 & 60 & Clear speech & $\begin{array}{l}\text { Full, good sense of } \\
\text { humour, witty }\end{array}$ & Independent & $\begin{array}{l}\text { Independent, } \\
\text { horseriding, } \\
\text { shopping, and } \\
\text { weight training }\end{array}$ & $\begin{array}{l}\text { Walking, needing } \\
\text { stick for long } \\
\text { distances }\end{array}$ & Generally good & Home with family \\
\hline 5 & F 23 & $\begin{array}{l}\text { Passenger in } \\
\text { road traffic } \\
\text { accident }\end{array}$ & $\begin{array}{l}\text { Left parietal, right } \\
\text { frontal, and } \\
\text { bilateral internal } \\
\text { capsule contusion }\end{array}$ & 6 & 7 & 50 & $\begin{array}{l}\text { Some speech, clear } \\
\text { non-verbal } \\
\text { communication }\end{array}$ & $\begin{array}{l}\text { Able to make } \\
\text { decisions about } \\
\text { needs, perfect } \\
\text { musical pitch }\end{array}$ & $\begin{array}{l}\text { By mouth with fluids, } \\
\text { supplementation } \\
\text { by gastrostomy }\end{array}$ & $\begin{array}{l}\text { Dependent but able } \\
\text { to instruci carers }\end{array}$ & $\begin{array}{l}\text { Walking with help or } \\
\text { high rollator frame }\end{array}$ & $\begin{array}{l}\text { Cheerful and } \\
\text { determined }\end{array}$ & Own home with carers \\
\hline 6 & M 27 & $\begin{array}{l}\text { Anoxia caused } \\
\text { by gunshot } \\
\text { wound }\end{array}$ & Not available & 4 & 4 & 24 & Normal & $\begin{array}{l}\text { Normal but reduced } \\
\text { working memory }\end{array}$ & Independent & Independent & Normal & $\begin{array}{l}\text { Good but lack of } \\
\text { motivation }\end{array}$ & Residential care \\
\hline 7 & F 16 & $\begin{array}{l}\text { Road traffic } \\
\text { accident }\end{array}$ & Not available & 8 & 8 & 28 & $\begin{array}{l}\text { Movement of thumb } \\
\text { and toe for basic } \\
\text { yes or no responses }\end{array}$ & Basic & Gastrostomy & Totally dependent & Totally dependent & Not assessable & $\begin{array}{l}\text { Still in rehabilitation } \\
\text { programme }\end{array}$ \\
\hline 8 & M 42 & $\begin{array}{l}\text { Anoxia after } \\
\text { coronary } \\
\text { bypass }\end{array}$ & Not available & 10 & 12 & 18 & $\begin{array}{l}\text { Non-verbal yes or no } \\
\text { responses }\end{array}$ & $\begin{array}{l}\text { Basic, shows pleasure } \\
\text { at family attention }\end{array}$ & Gastrostomy & Totally dependent & Totally dependent & Not assessable & $\begin{array}{l}\text { Still in rehabilitation } \\
\text { programme }\end{array}$ \\
\hline 9 & M 20 & $\begin{array}{l}\text { Anoxia after } \\
\text { road traffic } \\
\text { accident }\end{array}$ & $\begin{array}{l}\text { Low attenuation left } \\
\text { postero-temporal } \\
\text { extending to } \\
\text { frontoparietal } \\
\text { region, widespread } \\
\text { atrophic changes at } \\
\text { repeat scan }\end{array}$ & 5 & 7 & 15 & $\begin{array}{l}\text { Gestures and use of } \\
\text { computer }\end{array}$ & Good & By mouth & $\begin{array}{l}\text { Washing and } \\
\text { dressing upper } \\
\text { body, making } \\
\text { snacks, cleaning } \\
\text { teeth, and shaving }\end{array}$ & Dependent & Cheerful & $\begin{array}{l}\text { Discharged to } \\
\text { rehabilitation unit } \\
\text { nearer home to } \\
\text { continue } \\
\text { programme }\end{array}$ \\
\hline 10 & M 47 & $\begin{array}{l}\text { Anoxia after } \\
\text { cardiac arrest }\end{array}$ & Not available & 4 & 7 & 20 & Severe dysarthria & $\begin{array}{l}\text { Understanding of } \\
\text { current affairs and } \\
\text { complex } \\
\text { professional } \\
\text { information }\end{array}$ & $\begin{array}{l}\text { Gastrostomy and by } \\
\text { mouth }\end{array}$ & Dependent & Dependent & $\begin{array}{l}\text { Depressed with } \\
\text { insight into } \\
\text { disability }\end{array}$ & $\begin{array}{l}\text { Still in rehabilitation } \\
\text { programme }\end{array}$ \\
\hline 11 & M 17 & Air crash & Not available & 5 & 6 & 21 & $\begin{array}{l}\text { Use of } \\
\text { communication } \\
\text { aid }\end{array}$ & $\begin{array}{l}\text { Awareness of time, } \\
\text { places, and people }\end{array}$ & Independent & $\begin{array}{l}\text { Washing and } \\
\text { dressing with some } \\
\text { assistance }\end{array}$ & $\begin{array}{l}\text { Dependent, transfers } \\
\text { with help of one } \\
\text { person }\end{array}$ & Good & Home with family \\
\hline
\end{tabular}


the television and at humorous situations on the ward. $\mathrm{He}$ also showed pleasure when his wife visited and distress when she left. He remained totally dependent for all care and was discharged home. At five years after the brain damage he was still developing new responses.

Two patients were discharged to long term residential care units, one moved to her own house to be cared for by paid carers, four returned home to the care of their families, and four were still participating in inpatient rehabilitation programmes.

\section{Discussion}

Patients in the persistent vegetative state are generally thought to have a particularly bad prognosis, so much so that Jennett and Dyer regarded three months as the cut off point in discussions about assisting such patients to die. ${ }^{14}$ This has become particularly relevant since the case of Tony Bland, in which the courts accepted that withdrawing artificial feeding would not be illegal. There is also a feeling among doctors and the general public that such an approach is appropriate. ${ }^{30}$

One difficulty is knowing whether any recovery is possible from the persistent vegetative state if a rehabilitation programme is provided. Since the number of patients in the vegetative state is very small it is difficult to gain the necessary experience in their management in any single district health authority. This study examined the experience of a national specialist unit for people in the vegetative state. The patients were not selected on the expectation that they would recover, but it is impossible to say whether they were a representative sample of vegetative patients. Certainly, most patients had relatives who were determined that everything possible should be done to help recovery, and this may account for the high proportion of patients discharged home to the care of their families.

The first sign of awareness recorded was usually eye tracking. Some experts regard this as a reflex pattern, and it is therefore debatable whether this is a true sign of awareness. The more useful sign of responding to commands occurred between four and 12 months after brain damage. There are, however, problems in identifying the start of eye tracking and obeying commands since neither occurs suddenly, and there can be much uncertainty as to whether the responses are occurring by chance. There is also the risk that hopes for improvement can lead to the interpretation of any reflex movement as a meaningful response. The times given in this study for returning awareness were when an experienced team thought that the responses were more than chance findings. This gives some chance of variance in the time of possible first response, but it reflects the situation in the day to day management of vegetative patients.

Within these limitations the study shows that patients can regain awareness after more than four months in the persistent vegetative state. Some of the patients reached a high level of functioning in daily activities and mental state, making progress far beyond the expectations of experienced clinicians. Others remained severely disabled, though recovering sufficient mental ability to make decisions for themselves. Even the most profoundly disabled were able to take pleasure in their surroundings and, in the limits of their poor physical ability, to react with others. Placement depended more on family support than severity of disability, and some of the most profoundly disabled people were discharged to their homes at their families' request.

Only one patient (case 10) showed regular distress. It is a clinical impression that distress is more common among patients who have a good insight into their state while remaining severely physically disabled. This is not always the case, however, as shown by the patient in case 5, who remained cheerful and determined. Among the other patients there was no evidence that limited recovery was associated with depression or a feeling that a condition of severe disability was worse than non-sentience or death. This is a subjective view, but the impression gained was that signs of pleasure were far more common than those of distress.

It is difficult to identify factors associated with better levels of recovery. Computed tomography scans were not always available and showed only the early stages of brain damage. The two patients who were assaulted seemed to make a reasonably good recovery, but the other two who made a good recovery had suffered anoxia and traumatic brain damage respectively. It is, however, impossible to rule out an anoxic contribution in severe traumatic brain injury. A more detailed study is needed to identify prognostic factors that could help in making decisions about patients.

The longest period to eye tracking was three years, but this patient was still not communicating five years after the brain damage. All of the others had started eye tracking or obeying commands in the first year. This supports the statement in the BMA ethical committee's discussion document on the persistent vegetative state that no decision about withdrawal of artificial feeding should be made until at least one year after the onset of the brain damage. The occasional history of significant recovery after one year, as described in the introduction, will continue to complicate such decision making.

This study suffers from being a retrospective review of case notes. While a prospective study would be preferable, and one is under way, the rarity of the condition means that information about patients' prognoses would not be available for a considerable time. This retrospective study offers some clues to the possible prognoses of patients in the persistent vegetative state. There is much to learn about the benefits of rehabilitation programmes for severely brain damaged people, but the patterns of recovery shown by these patients offer hope that, as experience is gained, the outlook for such patients will improve.

1 Jennett B, Plum F. Persistent vegetative state after brain damage: a syndrome in search of a name. Lancet 1972;i:734-7.

2 Rosin A. Very prolonged unresponsive state following brain injury. Scand $f$ Rehabil Med 1978;10:33-78.

3 Hansotia PL. Persistent vegetative state. Review and report of electrodiagnostic studies in eight cases. Arch Neurol 1985;42:1048-52.

4 Craig CW, Muhlbauer MS, Watridge CB, Ray MW. Analysis of 76 civilian craniocerebral gunshot wounds. I Neurosurg 1986;65:9-14

5 Lobato L, Cordobes F, Rivas JJ, de la Fuente M, Montero A, Barcena A, et al Outcome from severe head injury related to the type of intracranial lesion. f Neurosurg 1983;59:762-74.

6 Bricolo A, Turazzi S, Feriotti G. Prolonged posttraumatic unconsciousness. I Neurosurg 1980;52:625-34.

7 Jennett B, Teasdale G, Galbraith S, Pickard J, Grant H, Braakman R, et al. Severe head injuries in three countries. $f$ Neurol Neurosurg Psychiatry 1977;40:291-8.

8 Mahoney WJ, D'Souza BJ, Haller JA, Rogers MC, Epstein MH, Freeman JM Long term outcome in children with severe head injury and prolonged coma. Pediatrics 1983;71:756-62.

9 Young B, Rapp RP, Norton JA, Haack D, Tibbs PA, Bean JR. Early prediction of outcome in head injured patients. I Neurosurg 1981;54:300-3.

10 Becker DP, Miller D, Ward JD, Greenberg P, Young HF, Sakalas R. The outcome from severe head injury with early diagnosis and intensive outcome from severe head injury with
treatment. I Neurosurg 1977;47:491-502.

11 Roberts AH. Severe accidental head injury: an assessment of long-term prognosis. London: Macmillan, 1979.

12 Higashi K, Sakata Y, Hatano M, Abiko S, Ihara K, Katayama S, et al. Epidemiological studies of patients with persistent vegetative state. $\mathcal{f}$ Neurol Neurosurg Psychiatry 1977;40:876-85.

13 Sazbon L, Costeff $\mathrm{H}$, Groswasser $\mathrm{Z}$. Epidemiological findings in traumatic post-comatose unawareness. Brain Injury 1992;4:359-62.

14 Jennett B, Dyer C. Persistent vegetative state and the right to die: the United States and Britain. BMF 1991;302:1256-8.

15 Jennett B. Letting vegetative patients die. BMF 1992;305:1305-6.

16 Braakman R, Jennett WB, Minderhound JM. Prognosis of the posttraumatic vegetative state. Acta Neurochir (Wien) 1988;95:49-52.

17 Levy DE, Knill-Jones RP, Plum F. The vegetative state and its prognosis following non-traumatic coma. Ann N Y Acad Sci 1978;315:293-306

18 Berrol S. Evolution and the persistent vegetative state. Fournal of Head Trauma Rehabilitation 1986;1:7-13.

19 Lyle DM, Pierce JP, Freeman EA, Bartrop R, Dorsch NWC, Fearnside MR, et al. Clinical course and outcome of severe head injury in Australia. I Neurosurg 1986;65:15-8.

20 Heiden JS, Small R, Caton W, Weiss M, Kurze T. Severe head injury: clinical assessment and outcome. Phys Ther 1983;63:1946-51. 
21 Steinbock B. Recovery from persistent vegetative state? The case of Carrie Coons. Hastings Cent Rep 1989;19:14-5.

22 Najenson T, Sazbon L, Fiselzon J, Becker E, Schechter I. Recovery of communicative functions after prolonged traumatic coma. Scand $\mathcal{f}$ Rehabil Med 1978;10:15-21.

23 Haig AJ, Reuss JM. Recovery from vegetative state of six months' duration associated with Sinemet (levodopa/carbidopa). Arch Phys Med Rehabil 1990;71:1081-3.

24 May PG, Kaelbling R. Coma of a year's duration with favourable outcome. Dis Nerv Syst 1968:29:837-40.

25 Levin HS, Saydjari C, Eisenberg HM, Foulkes M, Marshall LF, Ruff RM, et al. Vegetative state after closed head injury: a traumatic Data Bank report. Arch Neurol 1991:48:580-5.

26 Higashi K, Hatano M, Abiko S, Ihara K, Katayama S, Wakuta Y, et al. Five year follow up study of patients with persistent vegetative state. $\mathcal{f}$ Neuro Neurosurg Psychiatry 1981;41:552-4.

27 Rosenberg GA, Johnson SF, Brenner RP. Recovery of cognition after prolonged vegetative state. Ann Neurol 1977;2:167-8.

28 Arts WFM, Van Dongen HR, Duin JVH-V, Lammens E. Unexpected improvement after prolonged posttraumatic vegetative state. $f$ Neurol Neurosurg Psychiatry 1985;48:1300-3

29 Tanheco J, Kaplan PE Physical and surgical rehabilitation of patient after 6 year coma. Arch Phys Med Rehabil 1982;63:36-8.

304 out of 10 doctors back euthanasia law change (news). BMA News Review 1993;19:9. (April 1993.)

\title{
Patients in the persistent vegetative state: problems in their long term management
}

\author{
Keith Andrews
}

\begin{abstract}
Physicians responsible for the long term management of patients in the persistent vegetative state face several problems. These include deciding whether tube feeding is treatment or nutritional care, whether withdrawal of tube feeding is an appropriate form of management, what clinical advantage there is in active treatment; at what level of awareness can a patient be said to have a quality of life; and who should determine a patient's right to die. These problems are determined more by social, legal, emotional, cultural, religious, and economic forces than by clinical facts.
\end{abstract}

Patients in the persistent vegetative state have no obvious cognitive function and are generally thought to have a very poor prognosis. These factors have led to several inferences being drawn about such patients which have implications for their management: that they have no quality of life; that there is no advantage in keeping them alive; that they cannot feel distress if, say, their food is withdrawn; and that others must make decisions on their behalf. The recent case when the High Court was asked to agree to the removal of feeding from a young man in the persistent vegetative state has highlighted these issues. In this paper I address some of the problems faced by physicians responsible for the long term management of people with severe or profound disabilities.

\section{The case of Anthony Bland}

Anthony Bland was aged 18 when he suffered severe anoxic brain damage during the disaster at Hillsborough football ground three years ago. He remained in a vegetative state for three years and died when his nasogastric feeding was withdrawn. All of the expert witnesses in the court case agreed that there was no hope of any recovery, and the local health authority, supported by Anthony's parents, sought the court's permission to stop feeding by nasogastric tube to allow Anthony to die. This was the first case to come to the courts in England, although the principle has been accepted in some American states, Canada, and some other countries.

\section{IS FEEDING A TREATMENT?}

The main basis of the argument for the withdrawal of feeding was that feeding was a treatment and that it was acceptable for doctors not to treat someone with no hope of recovery. At the trial I suggested that treatment, by its very nature, was given to treat an abnormality and said that I could not understand what abnormality the food was supposed to be treating-its purpose being to supply normal nutrition to an otherwise healthy body. The arguments depended on the fact that the feeding required technology (the gastrostomy tube), special food, supervision by a dietitian, and insertion of the tube by a trained nurse. Although it is standard practice to provide prescribed preparations of food for nasogastric tubes, there is no reason, apart from the time needed for its preparation, why liquidised "normal" food should not be used. Similarly a dietitian's advice is desirable but not essential-few of us need a dietitian to advise us on our nutritional intake unless we require a special diet for a metabolic or primary nutritional disorder. It is, however, accepted that the tube is an abnormal or, more accurately, a technical method of feeding a patient. The tube is a method of overcoming a physical block to allow the provision of normal food to an otherwise healthy body. The tube is therefore the treatment, the food is not. Neither can be effective without the other, however, and the package, of tube and food, must therefore be the treatment.

\section{DEATH BY NATURAL CAUSES?}

Leaving aside these niceties, the purpose of withdrawing the nasogastric tube, and therefore the food, would be to end the life of the patient. In the trial much emphasis was placed on the opinion of most of the expert witnesses that if the tube was removed the cause of the death would not be the doctor but the original brain damage. Another point of view, however, is that the act of removing the tube would result in starvation, death being due to damage to previously healthy tissues secondary to the patient not being able to gain access to food. The same situation would arise in the "locked-in" syndrome, in which a patient is cognitively intact but totally paralysed because of a lesion in the pons, or in a case of fracture of all four limbs, as in a skiing accident. In such cases a patient would starve to death if food was not provided, but would the death be thought to be due to natural causes-brain damage or fractured limbs-or due to the withholding of food?

\section{A patient who has no quality of life?}

Quality of life is difficult to define, especially for someone unable to express any views. This is relevant because a person's quality of life is something which only that individual can decide-it depends on concepts of handicap rather than disability. Whatever our opinion of someone's quality of life, if that person disagrees then we must be wrong. An extreme point of view could be that patients in the persistent vegetative state have a good quality of life, since they are fed, watered, warm, safe, and without worries. Another view is that if they are unable to appreciate anything

\section{Putney, London}

Keith Andrews, director of

medical and research services

$B M 7$ 1993;306: 1600-2

\section{.}

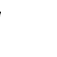

